\title{
Profil Penalaran Aljabaris Siswa Dalam Memecahkan Masalah Matematika Ditinjau dari Adversity Quotient
}

\author{
Irna Natalis Sanit ${ }^{1}$, Subanji ${ }^{1}$, I Made Sulandra ${ }^{1}$ \\ ${ }^{1}$ Pendidikan Matematika-Universitas Negeri Malang
}

\begin{tabular}{l}
\hline \hline INFO ARTIKEL \\
\hline Riwayat Artikel: \\
Diterima: 07-05-2019 \\
Disetujui: $15-09-2019$ \\
\hline
\end{tabular}

\section{Kata kunci:}

algebraic reasoning; solution to problem; adversity quotient; penalaran aljabaris; pemecahan masalah; adversity quotient

\author{
Alamat Korespondensi: \\ Irna Natalis Sanit \\ Pendidikan Matematika \\ Universitas Negeri Malang \\ Jalan Semarang 5 Malang \\ E-mail: Irnasanit24@gmail.com
}

\begin{abstract}
ABSTRAK
Abstract: The purpose of this study is to describe the algebraic reasoning of junior high school students in solving mathematical problems in terms of Adversity Quetients. The study was conducted in Tarus Self-help Junior High School. The stages of students' algebraic reasoning in solving problems were generalisation activities, transformation activities, and global metal-level activities. The instruments used in this study were ARP instruments (Adversity Response Profile), algebraic reasoning tests, and interview guidelines. The results of this study showed that the Climber students did algebraic reasoning on generalisation activities, transformation activities, and global metal-level activity. The Camper students only did algebraic reasoning on general activities. While Quitter students did not do algebraic reasoning on all activities.

Abstrak: Tujuan penelitian ini mendeskripsikan penalaran aljabaris siswa SMP dalam memecahkan masalah matematika ditinjau dari Adversity Quotient. Penelitian dilakukan di SMP Swadaya Tarus Kupang. Tahap penalaran aljabaris siswa dalam memecahkan masalah yaitu, yaitu aktivitas generalisasi, aktivitas transformasi, dan aktivitas level-meta global. Intrumen yang digunakan dalam penelitian ini adalah instrumen ARP (Adversity Response Profile), tes penalaran aljabaris, dan pedoman wawancara. Hasil penelitian menunjukkan bahwa siswa Climber melakukan penalaran aljabaris pada aktivitas generalisasi, aktivitas transformasi dan aktivitas level-meta global. Siswa Camper hanya melakukan penalaran aljabaris pada aktivitas generalisasi saja, sedangkan siswa Quitter tidak melakukan penalaran aljabaris pada semua aktivitas.
\end{abstract}

Kemampuan penalaran merupakan salah satu aspek penting bagi siswa dalam mempelajari matematika. Hal ini dipertegas (NTCM, 2000) bahwa standar proses pembelajaran matematika, meliputi pemecahan masalah, penalaran dan pembuktian, komunikasi, koneksi, dan representasi. Pentingnya penalaran bagi siswa juga merupakan tujuan dari kurikulum K13 (Permendikbud, 2016) yang menyatakan bahwa agar siswa meiliki kemampuan untuk menggunakan penalaran pada pola dan sifat, melakukan manipulasi matematika dalam generalisasi. Penalaran merupakan aktivitas mental atau kognitif melalui berpikir logis dan bersifat analitis (Subanji, 2011). Kemampuan penalaran aljabaris dapat digunakan untuk meningkatkan pemahaman siswa tentang konsep aljabar. Kajian dari aljabar ialah tentang struktur abstrak dan tentang penggunaan prinsp-prinsip struktur abstrak tersebut dalam menyelesaikan masalah matematika yang dilambangkan dengan simbol-simbol (NTCM, 2000). Dalam proses menyelesaikan masalah aljabar terjadi proses berpikir aljabaris atau penalaran aljabaris

Penalaran aljabaris menurut (Blanton \& Kaput, 2011), suatu proses berpikir dimana siswa melakukan generalisasi ide matematika dari sekumpulan fakta, menyusun generalisasinya melalui pernyataan dan mengekspresikan pernyataan tersebut dengan cara formal dan menyesuaikan usia. Menurut (Kieran, 2004) penalaran aljabaris adalah proses berpikir dengan menggunakan berbagai macam representasi untuk menyelesaikan situasi kuantitatif dengan cara relasional menggunakan simbol. (Kieran, 2004) berpendapat bahwa dalam menyelesaikan masalah aljabaris siswa melakukan aktivitas generalisasi (generational activity), aktivitas transformasi (transformational activity) dan aktivitas level-meta global (transformational activity). Penting untuk mengetahui penalaran aljabaris siswa. menurut (Rizal, 2011) salah satu tugas pendidik matematika adalah memperjelas proses berpikir siswa dalam mempelajari matematika dengan tujuan memperbaiki pembelajaran matematika di sekolah. Hal ini juga diperkuat dengan pendapat dari (Sanit, Subanji, \& Sulandra, 2019) yang mengatakan bahwa untuk meningkatkan kemampuan siswa dalam belajar matematika penting untuk mengetahui proses berpikir dan bernalar siswa. Dengan mengetahui proses berpikir dan bernalar siswa, guru dapat mengetahui letak kesalahan dan kesulitan siswa sehingga guru dapat memperbaiki kesalahan tersebut. 
Pemecahan masalah dapat digunakan untuk membantu siswa dalam mengembangkan kemampuan penalaran aljabaris. (Pehkonen, 1997) menyatakan bahwa pemecahan masalah telah diterima secara umum sebagai cara untuk meningkatkan keahlian berpikir. Hal ini juga sesuai dengan pendapat (NTCM, 2000), ketika memecahkan masalah matematika, mengharuskan siswa untuk memiliki pola pikir, ketekunan dan keingintahuan dan kepercayaan diri dalam berbagai situasi sehingga siswa dapat menghadapi berbagai masalah yang ada didalam kelas maupun di luar kelas. Dalam memecahkan masalah siswa harus melibatkan penerapan konsep dan keterampilan matematika yang dimiliki dalam berbagai situasi, termasuk masalah-masalah non-rutin atau masalah matematika yang belum pernah dijumpai siswa, terbuka, dan bersifat realistis.

Dalam pembelajaran matematika, siswa perlu bekerja lebih keras dibandingkan dengan pelajaran lain, tetapi siswa mengalami kesulitan dalam memecahkan masalah matematika. Selain itu, kemampuan siswa untuk mengatasi kesulitan dalam belajar dan memecahkan masalah matematika berbeda-beda (Murtafi'ah, 2016). Maka dari itu, dapat disimpulkan bahwa Adversity Quotient (AQ) memiliki peran dalam proses belajar matematika dan pemecahan masalah matematika. AQ merupakan kecenderungan seseorang dalam menghadapi masalah. (Stoltz, 1997) menyatakan bahwa AQ merupakan kecerdasan yang dimiliki seseorang untuk mnghadapi dan mengatasi kesulitan. Menurut (City, 2009) AQ merupakan salah satu faktor yang memengaruhi kemampuan akademik siswa, artinya semakin tinggi tingkat AQ siswa, maka semakin tinggi pula prestasi belajar matematikanya, dan sebaliknya semakin rendah tingkat AQ siswa, maka semakin rendah pula prestasi belajar matematikanya. (Stoltz, 1997) mengelompokkan AQ ke dalam tiga tipe, yaitu (1) climbers, merupakan sekelompok orang yang selalu berupaya mencapai puncak kesuksesan, siap menghadapi rintangan yang ada,dan selalu membangkitkan dirinya pada kesuksesan, (2) campers, merupakan sekelompok orang masih ada keinginan untuk menanggapi tantangan yang ada, tetapi tidak mencapai puncak kesuksesan dan mudah puas dengan apa yang sudah dicapai, dan (3) quitters, merupakan sekelompok orang yang lebih memilih menghindar dan menolak kesempatan yang ada, mudah putus asa, mudah menyerah, cenderung pasif, dan tidak bersemangat untuk mencapai puncak keberhasilan. Kecenderungan seseorang dalam menghadapi dan mengatasi kesulitan dapat diukur melalui Adversity Response Profile (ARP). Berdasarkan uraian tersebut, tujuan penelitian ini adalah mendeskripsikan Profil Penalaran Aljabaris Siswa Dalam Memecahkan Masalah Matematika Ditinjau Dari AQ (Adversity Quotient)

\section{METODE}

Penelitian ini adalah penelitian kualitatif dengan tujuan mendeskripsikan profil penalaran aljabaris siswa dalam memecahkan masalah matematika ditinjau dari AQ (Adversity Quotient). Untuk mendapatkan deskripsi data secara mendalam tentang profil penalaran aljabaris siswa dalam memecahkan masalah matematika ditinjau dari AQ (Adversity Quotient),.maka pertama peneliti membagi siswa berdasarkan kategori AQ menggunakan angket ARP(Adversity Response Profile) setelah itu siswa diberi tes berupa soal penalaran aljabaris yang diikuti dengan wawancara. Data hasil tes penalaran aljabaris dan data hasil wawancara digabung, kemudian dideskripsikan secara kualitatif, maka penelitian ini menggunakan pendekatan deskriptif kualitatif. Subjek penelitian ini adalah siswa kelas VIII SMP Swadaya Tarus Kupang, sebanyak tiga siswa berdasarkan kategori AQ, yaitu satu siswa Climber, satu siswa Camper, dan satu siswa Quitter. Alasan pemilihan subjek penelitian sebanyak tiga orang siswa adalah dengan maksud untuk mewakili setiap kategori $A Q$ dari keselurahan siswa. Instrumen yang digunakan dalam penelitian ini adalah angket ARP (Adversity Response Profile), tes penalaran aljabaris, dan pedoman wawancara. Teknik analisis data dalam penelitian ini dilakukan melalui reduksi data, penyajian data, dan penarikan kesimpulan (Miles \& Huberman, 1992).

\section{HASIL}

Berdasarkan data penelitian yang diperoleh dari hasil tes pemecahan masalah dan hasil wawancara diketahui bahwa kemampuan penalaran aljabaris yang dimiliki setiap subjek berbeda-beda berdasarkan kategori AQ (Adversity Quotient). Penalaran aljabaris setiap subjek dideskripsikan melalui tiga aktivitas penalaran aljabaris menurut (Kieran, 2004) yaitu (1) aktivitas generalisasi, (2) aktivitas transformasi, dan (3) aktivitas level-meta global. Berikut hasil penalaran aljabaris siswa berdasarkan kategori AQ.

\section{Penalaran Aljabaris Siswa Climber Aktivitas Generalisasi}

Subjek CL dalam menyelesaikan masalah matematika yang diberikan pada aktivitas generalisasi melakukan penalaran aljabaris dengan mengubah masalah dalam bentuk variabel dan menentukan variabel yaitu subjek menggunakan variabel $x$ untuk tinggi pavingblok berbentuk segienam dan variabel $y$ sebagai tinggi paving blok berbentuk persegi panjang. Berikut ditunjukkan hasil pekerjaan dan wawancara CL pada tabel 1. 
Tabel 1. Hasil Tes Tertulis dan Wawancara CL pada Aktivitas Generalisasi

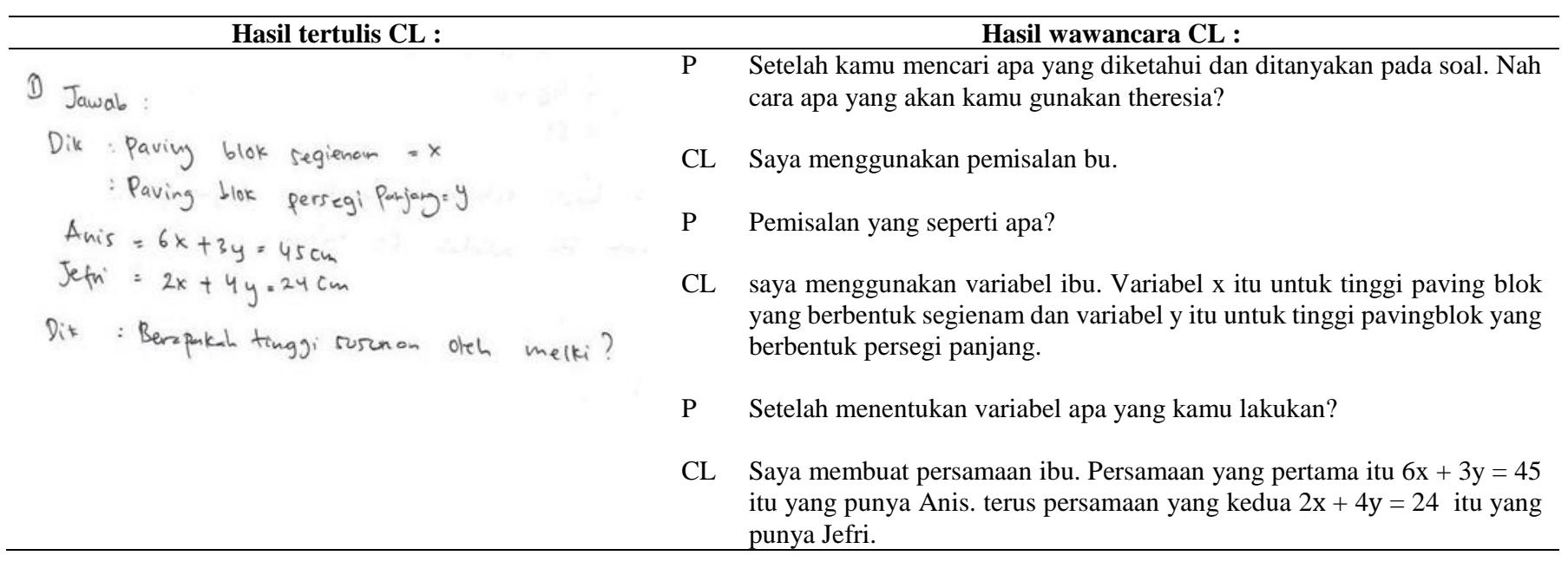

Pada hasil pekerjaan subjek dan hasil wawancara juga tampak bahwa CL1 melakukan penalaran aljabaris dengan merepresentasikan masalah dalam hubungan antar variabel yaitu subjek membuat hubungan antar jumlah paving blok segienam dan pavingblok persegi panjang sehingga menjadi persamaan-persamaan yaitu persamaan yang pertama $6 x+3 y=45 \mathrm{~cm}$ dan $2 x+4 y=24$. Jadi, berdasarkan tabel 1 dapat diketahui bahwa pada aktivitas generalisasi subjek CL melakukan penalaran aljabaris dengan mengubah masalah dalam bentuk variabel dan menentukan variabel serta merepresentasikan masalah dalam hubungan antar variabel.

\section{Aktivitas Transformasi}

Subjek CL dalam menyelesaikan masalah matematika pada aktivitas transformasi, langkah pertama subjek CL menggunakan metode eliminasi untuk memperoleh nilai dari variabel y. Dengan mengeliminasi persamaan $6 x+3 y=45$ dan persamaan $2 x+4 y=24$ setelah dieliminasi diperoleh nilai dari variabel y yaitu 3. Hasil pekerjaan dan wawancara CL ditunjukkan pada tabel 2 .

Tabel 2. Hasil Tes Tertulis dan Wawancara CL pada Aktivitas Transformasi

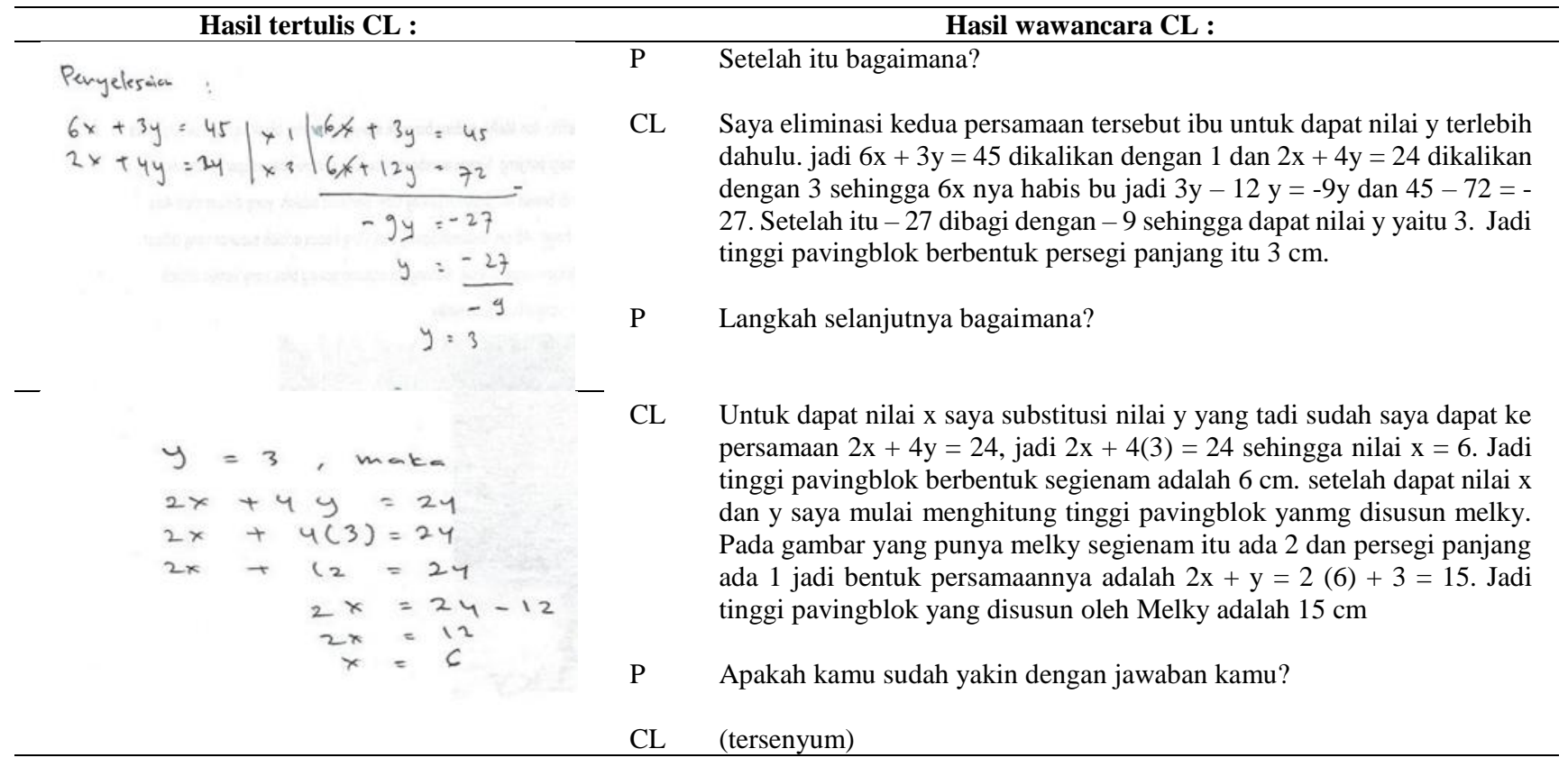


Pada hasil pekerjaan subjek dan hasil wawancara pada tabel 2 juga tampak bahwa CL1 menemukan nilai variabel $y$, subjek kemudian menggunakan metode substitusi untuk mencari nilai variabel $x$. Tampak bahwa subjek CL mensubstitusi nilai variabel $y$ ke persamaan $2 x+4 y=24$ dan memperleh nilai variabel $x$ yaitu 6. Jadi, berdasarkan tabel 2 dapat diketahui bahwa subjek CL melakukan penalaran aljabaris dengan menyelesaikan sistem persamaan linear dua variabel dengan metode eliminasi dan metode substitusi. Akan tetapi, tidak semua indikator penalaran aljabaris pada aktivitas transformasi dilakukan subjek CL.

\section{Aktivitas Level-Meta Global}

Pada aktivitas level-Meta global subjek CL melakukan penalaran aljabaris dengan menyelesaikan dan menemukan solusi dari permasalahan matematis yang diberikan. Berikut akan ditunjukkan hasil pekerjaan dan wawancara CL pada tabel 3.

Tabel 3. Hasil tes tertulis dan wawancara CL pada aktivitas Level-Meta Global

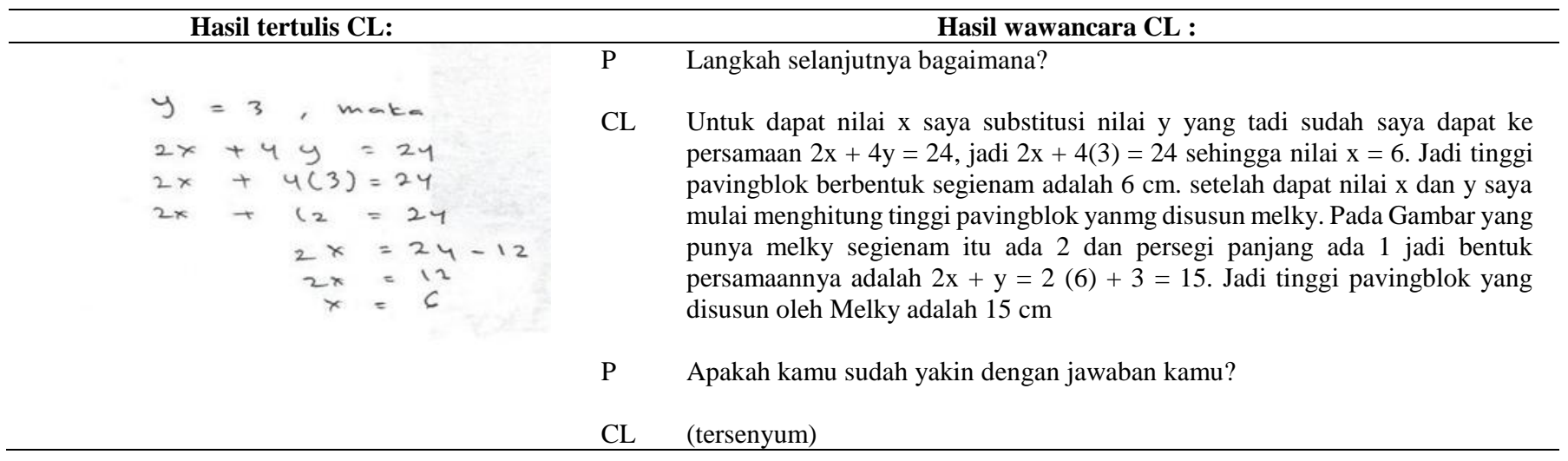

Pada hasil pekerjaan subjek dan hasil wawancara pada tabel 3, setelah menemukan nilai variabel $x$ dan nilai variabel $y$ subjek menjawab pertanyaan dengan mensubstitusi nilai variabel $x$ dan nilai variabel $y$ ke persamaan $2 x+y$ sehingga memperoleh 15. Berdasarkan tabel 3 dapat diketahui bahwa pada aktivitas level-meta global subjek CL melakukan penalaran aljabaris dengan menyelesaikan dan menemukan solusi dari permasalahan matematis yang diberikan.

\section{Aktivitas Generalisasi}

Subjek C dalam menyelesaikan masalah matematika yang diberikan pada aktivitas generalisasi adalah pertama subjek $\mathrm{C}$ tampak menuliskan apa yang diketahui dan ditanya dari soal, setelah itu subjek mencoba mengubah masalah ke dalam bentuk variabel dan menentukan variabel. Dengan menggunakan $x$ sebagai variabel dari segienam dan $y$ sebagai variabel dari persegi pajang, tetapi tidak tampak dengan jelas makna dari variabel $x$ dan variabel $y$. Berikut ditunjukkan hasil pekerjaan dan wawancara CL pada tabel 4.

Tabel 4. Hasil Tes Tertulis dan Wawancara C pada Aktivitas Generalisasi

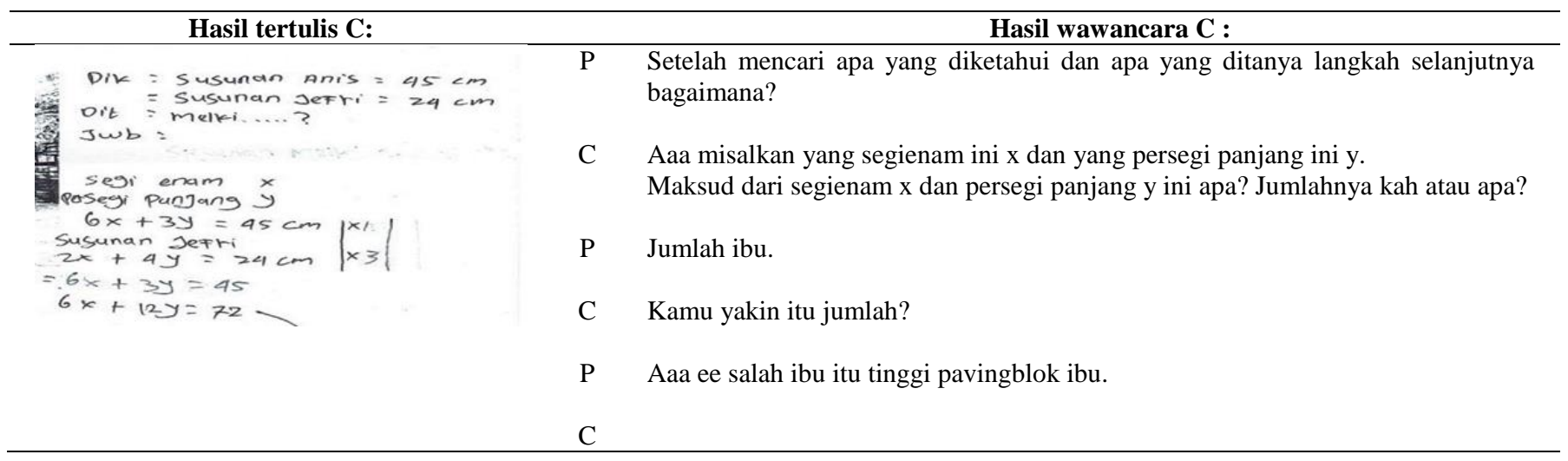


Pada tabel 4, hasil wawancara menunjukkan bahwa $\mathrm{C}$ memahami makna variabel yang digunakan, yaitu variabel $x$ sebagai tinggi dari paving blok yang berbentuk segienam dan variabel $y$ sebagai tinggi dari paving blok yang berbentuk persegi panjang. Setelah itu, tampak bahwa subjek $\mathrm{C}$ merepresentasikan masalah dalam hubungan antar variabel dengan membuat persamaan $6 x+3 y=45$ dan persamaan $2 x+4 y=24$. Jadi, berdasarkan tabel 4 dapat diketahui bahwa pada aktivitas generalisasi subjek $\mathrm{C}$ melakukan penalaran aljabaris dengan mengubah masalah dalam bentuk variabel dan menentukan variabel,serta merepresentasikan masalah dalam hubungan antar variabel.

\section{Aktivitas Transformasi}

Subjek C dalam menyelesaikan masalah matematika pada aktivitas transformasi, berdasarkan hasil pekerjaan tertulis subjek pada Tabel 4 dapat diketahui bahwa subjek mencoba mencoba menggunakan metode eliminasi dengan mengeliminasi persamaan $6 x+3 y=45$ dan persamaan $2 x+4 y=24$ untuk mencari nilai dari variabel $x$ atau variabel $y$ tetapi terlihat bahwa subjek tidak melanjutkan pekerjaannnya dikarenakan subjek merasa kesulitan dalam mengeliminasi persamaan. Hal ini diungkapkan subjek ketika melakukan kegiatan wawancara dengan peneliti. Berikut adalah hasil wawancara peneliti dengan subjek C.

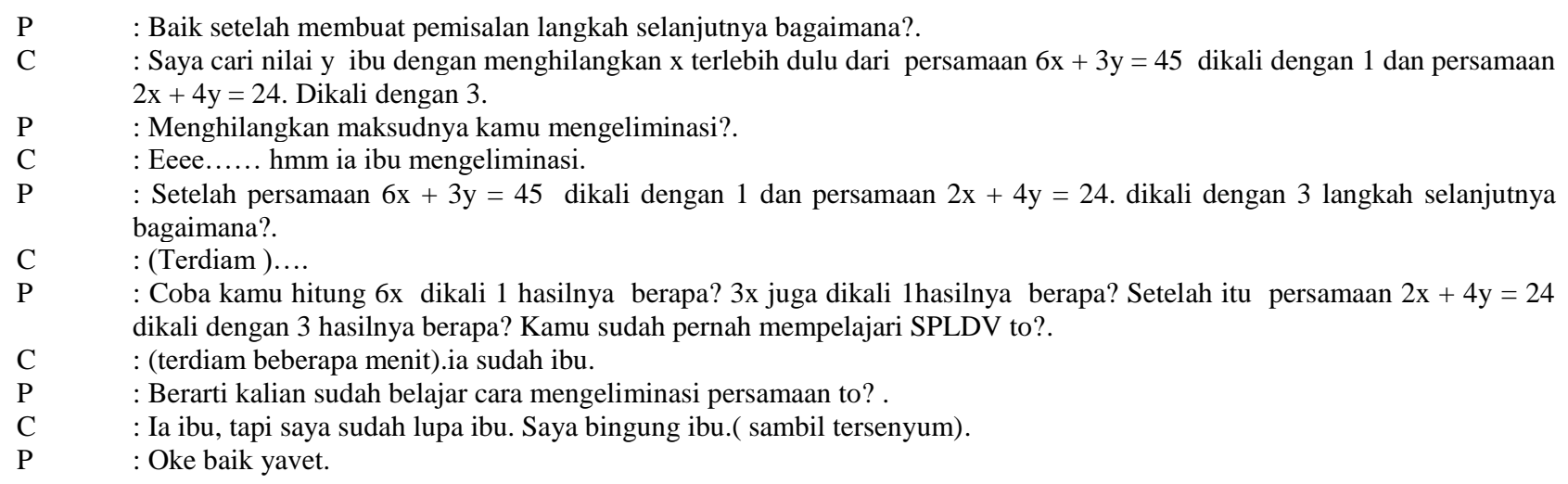

Berdasarkan hasil pekerjaan subjek $\mathrm{C}$ dan hasil wawancara yang dilakukan dengan peneliti, dapat diketahui bahwa dalam menyelesaikan masalah matematika yang diberikan, pada aktivitas transformasi subjek $\mathrm{C}$ tidak melakukan penalaran aljabaris karena subjek $\mathrm{C}$ mengalami kesulitan dalam mengoperasikan persamaan.

\section{Aktivitas Level-Meta Global}

Pada aktivitas level-Meta global subjek C tidak melakukan penalaran aljabaris karena langkah penyelesaian masalah yang diberikan terhenti pada aktivitas transformasi.

\section{Penalaran Aljabaris Siswa Quitter Aktivitas Generalisasi}

Pada aktivitas generalisasi subjek Q dalam menyelesaikan masalah matematika yang diberikan tampak bahwa, langkah pertama yang dilakukan subjek Q adalah menuliskan apa yang diketahui dan apa yang ditanya dari soal. Selanjutnya, subjek Q langsung mengurangkan angka-angka yang diketahui tersebut yaitu 45 dan 24 dan memperoleh. Dari hasil pekerjaan subjek Q dapat diketahui bahwa subjek tidak melakukan aktivitas generalisasi. Berikut ditunjukkan hasil pekerjaan dan wawancara CL pada tabel 6. Berdasarkan tabel 6 dapat diketahui bahwa pada aktivitas generalisasi subjek Q tidak melakukan penalaran aljabar.

\section{Aktivitas Transformasi dan Aktivitas Level-Meta Global}

Berdasarkan hasil pekerjaan tertulis subjek Q dan hasil wawancara yang dilakukan dengan peneliti pada tabel 6 dapat diketahui bahwa dalam menyelesaikan masalah matematika yang diberikan subjek Q tidak melakukan penalaran aljabaris pada aktivitas transformasi dan aktivitas level-meta global. 
Tabel 6. Hasil Tes Tertulis dan Wawancara C pada Aktivitas Generalisasi

\begin{tabular}{|c|c|c|}
\hline Hasil tertulis Q: & \multicolumn{2}{|r|}{ Hasil wawancara Q : } \\
\hline \multirow{10}{*}{ 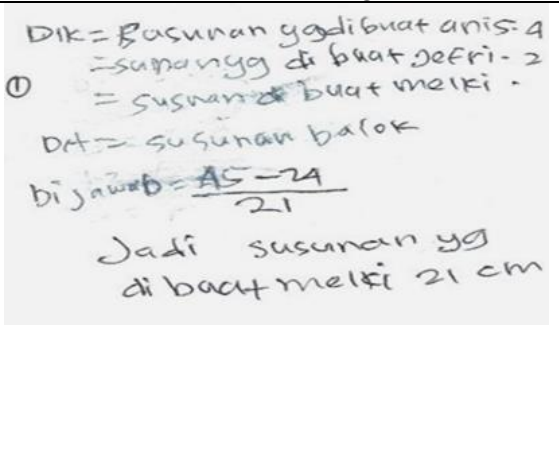 } & $\mathrm{P}$ & Setelah membaca soal apa yang pertama kali kamu pikirkan? \\
\hline & Q & $\begin{array}{l}\text { Aa susunan yang dibuat Anis } 45 \text {, susunan yang dibuat Jefri 24. Berapakah susunan } \\
\text { yang dibuat Melki? }\end{array}$ \\
\hline & $\mathrm{P}$ & Oh berarti pertama kamu mencari apa yang diketahui dan apa yang ditanya dari soal? \\
\hline & Q & Iya ibu. \\
\hline & $\mathrm{P}$ & Na langkah selanjutnya bagaimana untuk menyelesaikan permasalahan ini? \\
\hline & Q & $\begin{array}{l}\text { Eeee bagaimana e... karena punya Anis } 45 \text { dan Punya Jefri } 24 \text { maka } 45 \text { dikurang } \\
\text { dengan } 24 \text { adalah } 21 \text {. Jadi susunan yang dibuat Melki adalah } 21\end{array}$ \\
\hline & $\mathrm{P}$ & Kamu yakin dengan jawaban kamu? \\
\hline & $\mathrm{Q}$ & Eeee ( tersenyum) \\
\hline & $\mathrm{P}$ & Apakah tidak ada cara lain untuk menyelesaikan masalah nomor 1 ini? \\
\hline & $\mathrm{Q}$ & Eeee saya tidak tahu ibu. \\
\hline
\end{tabular}

\section{PEMBAHASAN}

Berdasarkan hasil penelitian yang telah dipaparkan diatas, berikut adalah pembahasan mengenai penalaran aljabaris siswa dalam memecahkan masalah matematika ditinjau dari AQ. Tahapan penalaran aljabaris dalam penelitian ini merujuk pada teori yang dikembangkan oleh (Kieran, 2004), meliputi aktivitas generalisasi, aktivitas transformasi, dan aktivitas level-meta global. Adapun profil penalaran aljabaris siswa climber, camper, dan quitter.

\section{Profil Penalaran Aljabaris Siswa dalam Memecahkan Masalah Matematika pada Aktivitas Generalisasi}

Aktivitas generalisasi merupakan aktivitas yang berkaitan dengan pembentukan ekspresi dan persamaan. Hal ini juga sejalan dengan pendapat yang dikemukakan oleh (Mashuri \& Rochmad, 2018), "kemampuan penalaran aljabar pada jenjang kegiatan generasional terbatas pada kemampuan untuk membentuk ekspresi dan persamaan dalam objek aljabar”. Dalam peneltian ini siswa dikatakan melakukan penalaran aljabaris pada aktivitas generaliasi jika siswa mengubah masalah kedalam bentuk variabel dan menentukan variabel serta siswa merepresentasikan masalah dalam hubungan antar variabel. Penalaran aljabaris siswa pada aktivitas generaliasi disajikan pada tabel 7 .

Tabel 7. Profil Penalaran Aljabaris Siswa pada Aktivitas Generalisasi

\begin{tabular}{|c|c|c|c|}
\hline \multirow{2}{*}{$\begin{array}{c}\text { Penalaran } \\
\text { Aljabaris }\end{array}$} & \multicolumn{3}{|c|}{ Siswa berdasarkan kategori AQ (Adversity Quotient) } \\
\hline & Siswa Climber & Siswa Camper & Siswa Quitter \\
\hline $\begin{array}{l}\text { Aktivitas } \\
\text { Generalisasi }\end{array}$ & $\begin{array}{l}\text { Melakukan penalaran aljabaris pada aktivitas } \\
\text { generalisasi dengan mengubah masalah dalam } \\
\text { bentuk variabel dan menentukan variabel serta } \\
\text { merepresentasikan masalah dalam hubungan } \\
\text { antar variabel }\end{array}$ & $\begin{array}{l}\text { Melakukan penalaran aljabaris pada aktivitas } \\
\text { generalisasi dengan mengubah masalah dalam } \\
\text { bentuk variabel dan menentukan variabel serta } \\
\text { merepresentasikan masalah dalam hubungan } \\
\text { antar variabel }\end{array}$ & $\begin{array}{l}\text { Tidak } \\
\text { melakukan } \\
\text { penalaran } \\
\text { aljabaris }\end{array}$ \\
\hline
\end{tabular}

Berdasarkan tabel 7, dapat diketahui bahwa pada aktivitas generalisasi siswa Climber melakukan penalaran aljabaris dengan mengubah masalah dalam bentuk variabel dan menentukan variabel serta merepresentasikan masalah dalam hubungan antar variabel. Menurut (Inganah, 2015), penalaran aljabar pada umumnya melibatkan penggunaan simbol, namun penalaran dengan menggunakan simbol belum tentu penalaran aljabar. Siswa CL menggunakan huruf $x$ tinggi dari pavingblok berbentuk segienam dan huruf $y$ sebagai tinggi dari pavingblok yang berbentuk persegipanjang. Ketika merepresentasikan masalah dalam hubungan antar variabel siswa CL membuat persamaan $6 x+3 y=45$ yang diperoleh dari pavingblok yang disusun oleh Anis dan $2 x+4 y=24$ yang diperolah dari pavingblok yang disusun oleh Jefri.

Tabel 7 diketahui bahwa siswa Camper juga melakukam penalaran aljabaris pada aktivitas generalisasi dengan mengubah masalah dalam bentuk variabel dan menentukan variabel serta merepresentasikan masalah dalam hubungan antar variabel. Siswa Camper menggunakan huruf $x$ sebagai variabel dari tinggi pavingblok yang berbentuk segienam dan menggunakan huruf $y$ sbegai variabel dari timggi pavingblok yang berbentuk persegipanjang. Dan merepresentasikan masalah dalam hubungan antar variabel dengan dengan membuat persamaan yaitu $6 x+3 y=45$ dan $2 x+4 y=24$. Siswa $Q u i t t e r$ dalam menyelesaikan masalah matematika yang diberikan tidak melakukan penalaran aljabaris pada aktivitas generalisasi, aktivitas transfromasi dan aktivitas level-meta globel. Ketika menyelesaikan permasalahan yang diberikan, siswa Quitter tidak menggunakan indikator penalaran aljabaris pada ketiga aktivitas tersebut. 
Jadi, hanya siswa Climber dan siswa Camper yang melakukan penalaran aljabaris pada aktivitas generalisasi dengan mengubah masalah kedalam bentuk variabel dan menentukan variabel serta siswa merepresentasikan masalah dalam hubungan antar variabel.

\section{Profil Penalaran Aljabaris Siswa dalam Memecahkan Masalah Matematika pada Aktivitas Transformasi}

Aktivitas transformasi merupakan kegiatan yang berkaitan dengan perubahan berbasis pada aturan. Pernyataan ini sejalan dengan pendapat (Mashuri \& Rochmad, 2018), yang menyatakan bahwa "siswa dikatakan sampai pada tahap atau jenjang kegiatan transformasi jika dalam menyelesaikan soal siswa menngunakan berbagai metode penyelesaian salah satunya metode substitusi". Dalam peneltian ini, siswa dikatakan melakukan penalaran aljabaris pada aktivitas transformasi jika siswa menentukan bentuk sistem persamaan linear dua variabel yang ekuivalen, menyelesaikan sistem persamaan linear dua variabel dengan metode eliminasi, menyelesaikan sistem persamaan linear dengan metode substitusi, dan menyelesaikan sistem persamaan linear dua variabel dengan metode grafik. Penalaran aljabaris siswa pada aktivitas transformasi akan disajikan pada tabel 8.

Berdasarkan tabel 8, diketahui bahwa hanya siswa Climber yang melakukan penalaran aljabaris pada aktivitas transformasi dengan menyelesaikan bentuk persamaan linear dua variabel menggunakan metode eliminasi dan menyelesaikan bentuk persamaan linear dua variabel menggunakan metode substitusi. Pertama, siswa CL menggunakan metode eliminasi untuk memperoleh nilai variabel $y$. Setelah menemukan nilai $y$, siswa kemudian menggunakan metode substitusi untuk mencari nilai variabel $x$ sedangkan siswa Camper tidak melakukan penalaran aljabaris pada aktivitas trasnformasi karena, berdasarkan hasil pekerjaan tertulis dan hasil wawancara yang dilakukan peneliti diketahui bahwa siswa Camper kesulitan dalam menggunakan metode eliminasi untuk mencari nilai dari salah satu variabel yang telah ditentukan. Menurut (Yusnia \& Fitriyani, 2017), masih banyak siswa yang melakukan kesalahan dalam proses eliminasi dan substitusi khususnya pada operasi perkalian, penjumlahan, dan pengurangan pada bentuk aljabar ketika menyelesaikan soal cerita sistem persamaan linear dua variabel.

Tabel 8. Profil Penalaran Aljabaris Siswa pada Aktivitas Transformasi

\begin{tabular}{|c|c|c|c|}
\hline \multirow{2}{*}{$\begin{array}{l}\text { Penalaran } \\
\text { Aljabaris }\end{array}$} & \multicolumn{3}{|c|}{ Siswa berdasarkan kategori AQ (Adversity Quotient) } \\
\hline & Siswa Climber & Siswa Camper & Siswa Quitter \\
\hline $\begin{array}{c}\text { Aktivitas } \\
\text { Transformasi }\end{array}$ & $\begin{array}{l}\text { Melakukan penalaran aljabaris pada aktivitas transformasi, dengan } \\
\text { menyelesaikan bentuk persamaan linear dua variabel menggunakan } \\
\text { metode eliminasi dan menyelesaikan bentuk persamaan linear dua } \\
\text { variabel menggunakan metode substitusi }\end{array}$ & $\begin{array}{l}\text { Tidak melakukan } \\
\text { penalaran } \\
\text { aljabaris }\end{array}$ & $\begin{array}{l}\text { Tidak melakukan } \\
\text { penalaran } \\
\text { aljabaris }\end{array}$ \\
\hline
\end{tabular}

Jadi, pada aktivitas transformasi hanya siswa Climber yang melakukan penalaran aljabaris dengan menyelesaikan bentuk persamaan linear dua variabel menggunakan metode eliminasi dan menyelesaikan bentuk persamaan linear dua variabel menggunakan metode substitusi. Ada beberapa indikator penalaran aljabaris pada aktivitas transformasi yang tidak dilakukan siswa yaitu menentukan bentuk sistem persamaan linear dua variabel yang ekuivalen dan menyelesaikan bentuk persamaan linear dua variabel dengan metode grafik tidak dilakukan oleh siswa. Berdasarkan hasil wawancara yang dilakukan peneliti dengan masing-masing siswa diketahui bahwa siswa kesulitan melakukan kedua indikator tersebut dikarenakan dalam pembelajaran yang dilakukan tidak terbiasa menggunakan kedua indikator tersebut. Siswa lebih cenderung untuk mencontoh apa yang dilakukan oleh guru. Menurut (Sobel \& Maletsky, 2001), "pembelajaran matematika yang rutin seperti ini menjadikan kebermaknaan belajar siswa relatif rendah sehingga membosankan dan mengurangi minat belajar siswa".

\section{Profil Penalaran Aljabaris Siswa dalam Memecahkan Masalah Matematika pada Aktivitas Level-Meta Global}

Aktivitas level-meta global merupakan suatu kegiatan yang melibatkan aljabar sebagai suatu alat baik dalam memecahkan persoalan aljabar maupun persoalan lain di luar aljabar. Hal ini sejalan dengan pendapat (Mashuri \& Rochmad, 2018), yang menyatakan bahwa "pada jenjang level-meta global peserta didik sudah mampu menggunakan pengetahuan aljabarnya sebagai suatu alat untuk memecahkan permasalahan dalam lingkup aljabar maupun di luar aljabar". Dalam penelitian ini siswa dikatakan melakukan penalaran aljabaris pada aktivitas level-meta gobal jika siswa menyelesaikan dan menemukan solusi dari permasalahan matematis dan memecahkan masalah yang berkaitan dengan bidang ilmu lain. Penalaran aljabaris siswa pada aktivitas level-meta global disajikan pada tabel 9. 
Tabel 9. Profil Penalaran Aljabaris Siswa pada Aktivitas Level-Meta Global

\begin{tabular}{|c|c|c|c|}
\hline \multirow{2}{*}{$\begin{array}{c}\text { Penalaran } \\
\text { Aljabaris }\end{array}$} & \multicolumn{3}{|c|}{ Siswa berdasarkan kategori AQ (Adversity Quotient) } \\
\hline & Siswa Climber & Siswa Camper & Siswa Quitter \\
\hline $\begin{array}{l}\text { Aktivitas Level- } \\
\text { Meta Global }\end{array}$ & $\begin{array}{l}\text { Melakukan penalaran aljabaris pada aktivitas level-meta global } \\
\text { dengan menyelesaikan dan menemukan solusi dari permasalahan } \\
\text { matematis yang diberikan }\end{array}$ & $\begin{array}{l}\text { Tidak melakukan } \\
\text { penalaran aljabaris }\end{array}$ & $\begin{array}{l}\text { Tidak melakukan } \\
\text { penalaran aljabaris }\end{array}$ \\
\hline
\end{tabular}

Berdasarkan tabel 9, maka dapat diketahui bahwa pada aktivitas level-meta global hanya siswa Climber yang melakukan penalaran aljabaris dengan menyelesaikan dan menemukan solusi dari permasalahan matematis yang diberikan, sedangkan siswa Camper dan Quitter tidak melakukan penalaran aljabaris pada aktivitas ini. Hal ini sesuai dengan hasil penelitian yang dilakukan oleh (Mashuri \& Rochmad, 2018), bahwa siswa telah memiliki kompetensi berpikir aljabar pada tingkat generalisasi dan transformasi, namun tingkat level-meta global masih belum memuaskan.

Merujuk pada penaralan aljabaris yang dikemukakan oleh (Kieran, 2004) secara keseluruhan siswa dengan kategori AQ Climber dalam menyelesaikan masalah matematika yang diberikan, siswa Climber melakukan penalaran aljabaris pada aktivitas generalisasi dengan mengubah masalah dalam bentuk variabel dan menentukan variabel serta merepresentasikan masalah dalam hubungan antar variabel. Melakukan penalaran aljabaris pada aktivitas transformasi dengan menyelesaikan bentuk persamaan linear dua variabel dengan metode eliminasi dan substitusi. Walaupun ada beberapa indikator penalaran aljabar pada aktivitas transformasi yang tidak dilakukan. Serta siswa Climber melakukan penalaran aljabaris pada aktivitas level-meta global dengan menyelesaikan dan menemukan solusi dari permasalahan matematis. Ketika menyelesaikan permasalahan matematis yang diberikan, siswa Climber berusaha menemukan solusi dan jawaban untuk menyelesaikan masalah tersebut dengan pengetahuan yang dimilikinya. Hal ini terlihat dari hasil tes penalaran aljabar dan hasil wawancara yang dilakukan dengan peneliti. Pernyataan diatas diperkuat dengan teori dari (Stoltz, 1997), yaitu orang dengan tipe Climber adalah tipe orang yang selalu berusaha mencapai puncak kesuksesan, siap menghadapi rintangan yang ada, dan selalu membangkitkan dirinya pada kesuksesan. Hasil peneltian ini juga didukung oleh penelitian terdahulu yang dilakukan oleh (Irianti, 2015) yang menyatakan bahwa dari hasil wawancara dan hasil pekerjaan siswa, selama siswa menyelesaikan masalah siswa tidak pernah mengeluh terhadap masalah yang diberikan. Jika siswa mengalami keraguan dalam menyelesaikan masalah, siswa tidak pernah putus asa dan selalu berusaha untuk bisa menyelesaikan masalah tersebut sehingga mendapat hasil yang terbaik.

Merujuk pada penaralan aljabar yang dikemukakan oleh (Kieran, 2004) secara keseluruhan siswa dengan kategori AQ Camper dalam menyelesaikan masalah matematika yang diberikan hanya melakukan penalaran aljabaris pada aktivitas generalisasi dengan mengubah masalah dalam bentuk variabel dan menentukan variabel serta merepresentasikan masalah dalam hubungan antar variabel. Ketika menyelesaikan permasalahan matematis yang diberikan berdasaran hasil wawancara yang dilakukan dengan peneliti diketahui bahwa siswa Camper mudah menyerah. Pernyataan diatas juga diperkuat dengan teori dari (Stoltz, 1997) yaitu siswa dengan tipe Camper adalah tipe orang yang mudah putus asa dengan apa yang sudah dicapai. Hasil penelitian ini juga didukung oleh penelitian yang dilakukan oleh (Marpaung, 2007) yang menyatakan bahwa orang dengan tipe AQ Camper memiliki sikap motivasi rendah dalam belajarnya.

Merujuk pada penaralan aljabar yang dikemukakan oleh (Kieran, 2004) secara keseluruhan siswa kategori AQ Quitter dalam menyelesaikan masalah matematika yang diberikan tidak melakukan penalaran aljabaris. Berdasarkan hasil pekerjaan tes penalaran aljabar dan hasil wawancara yang dilakukan peneliti dengan masing-masing siswa Quitter diketahui bahwa ketika menyelesaikan masalah matematika yang diberikan siswa mudah putus asa dan tidak memilki kemauan untuk menyelesaikan masalah tersebut. Hal ini sesuai dengan teori oleh (Stoltz, 1997) yang menyatakan bahwa orang dengan tipe Quitter adalah tipe orang yang mudah putus asa, mudah menyerah, dan tidak bergairah untuk mencapai puncak keberhasilan. Hasil penelitian ini juga didukung oleh penelitian terdahulu yang dilakukan oleh (Irianti, 2015) yang menyatakan bahwa ketika siswa menyelesaikan masalah, siswa mudah putus asa dalam menyelesaikan masalah. Pada saat siswa mengalami kesulitan untuk menyelesaikan masalah yang ada, siswa tidak mau mencoba untuk menyelesaikan masalah tersebut.

\section{SIMPULAN}

Berdasarkan hasil penelitian dan pembahasan diperoleh kesimpulan bahwa penalaran aljabaris siswa Climber dalam memecahkan masalah matematika yang diberikan, meliputi (1) aktivitas generalisasi siswa dengan kategori AQ Climber melakukan penalaran aljabaris dengan mengubah masalah dalam bentuk variabel dan menentukan variabel serta merepresentasikan masalah dalam hubungan antar variabel; (2) aktivitas transformasi siswa dengan kategori AQ Climber melakukan penalaran aljabaris dengan menyelesaikan bentuk persamaan linear dua variabel dengan metode eliminasi dan substitusi. Walaupun ada beberapa indikator penalaran aljabar pada aktivitas transformasi yang tidak dilakukan; (3) aktivitas level-meta global siswa dengan kategori AQ Climber melakukan penalaran aljabaris dengan menyelesaikan dan menemukan solusi dari permasalahan matematis. 
Penalaran aljabaris siswa Camper dalam memecahkan masalah matematika yang diberikan hanya melakukan penalaran pada aktivitas generalisasi dengan mengubah masalah dalam bentuk variabel dan menentukan variabel serta merepresentasikan masalah dalam hubungan antar variabel. Aktivitas penalaran aljabaris siswa Camper terhenti pada aktivitas generalisasi, sedangkan siswa Quitter tidak melakukan penalaran aljabaris pada semua aktivitas.

\section{DAFTAR RUJUKAN}

Blanton, M. L., \& Kaput, J. J. (2011). Functional Thinking as a Route into Algebra in the Elementary Grades. In Early Algebraization (pp. 5-23). Springer.

City, Q. (2009). The Adversity Quotient and Academic Performance Among College Students at St. Joseph'scollege, Quezon City. St. Joseph's College.

Inganah, S. (2015). Proses Berpikir Aljabar Symbolic Hight Jumping dalam Menggeneralisasi Pola melalui Pendekatan Semiotik. Disertasi tidak diterbitkan. Universitas Negeri Malang, Malang.

Irianti, N. P. (2015). Proses Berpikir Siswa SMP dalam Menyelesaikan Masalah Matematika SPLDV Ditinjau dari Adversity Quotient. Disertasi tidak diterbitkan. Universitas Negeri Malang, Malang.

Kieran, C. (2004). Algebraic Thinking in the Early Grades: What is it. The Mathematics Educator, 8(1), $139-151$.

Marpaung, Y. (2007). Karakteristik PMRI (Pendidikan matematika realistik indonesia). Disajikan pada Penataran dan Lokakarya Widyaiswara Matematika LPMP Angkatan I dan II, di PPPG Matematika Yogyakarta.

Mashuri, M., \& Rochmad, R. (2018). Kompetensi Mahasiswa dalam Algebraic Thinking Berbasis Kieran's Theory pada Mata Kuliah Pengantar Struktur Aljabar. PRISMA, Prosiding Seminar Nasional Matematika, 1, 663-668.

Miles, M. B., \& Huberman, A. M. (1992). Qualitative Data Analysis: The Source Book of New Methods. Jakarta: UI-Press.

Murtafi'ah, W. (2016). Kemampuan Berpikir Logis Mahasiswa dengan Adversity Quotient Tipe Climber dalam Pemecahan Masalah Geometri. Jurnal Math Educator Nusantara: Wahana Publikasi Karya Tulis Ilmiah di Bidang Pendidikan Matematika, 2(1).

NTCM. (2000). Principles and Standards for Schools Mathematics.

Permendikbud. (2016). Peraturan Menteri Pendidikan dan Kebudayaan (Permendikbud) Republik Indonesia Nomor 8 Tahun 2016 tentang Buku yang digunakan oleh Satuan Pendidikan.

Rizal, M. (2011). Proses Berpikir Siswa SD Berkemampuan Matematika Tinggi dalam Melakukan Estimasi Masalah Berhitung. Prosiding Seminar Nasional Penelitian, Pendidikan, dan Penerapan MIPA Tanggal, 14, 19-28.

Sanit, I. N., Subanji, S., \& Sulandra, I. M. (2019). Profil Penalaran Aljabaris Siswa dalam Memecahkan Masalah Matematika Ditinjau dari Adversity Quotient. Jurnal Pendidikan: Teori, Penelitian, dan Pengembangan, 4(9), 1213-1221.

Sobel, A. M., \& Maletsky, M. E. (2001). Teaching Mathematics. London: Pearson Education.

Stoltz, P. G. (1997). Adversity Quotient: Turning Obstacles into Opportunities. John Wiley \& Sons.

Subanji. (2011). Teori Berpikir Pseudo Penalaran Kovariasional. Malang: UM Press.

Yusnia, D., \& Fitriyani, H. (2017). Identifikasi Kesalahan Siswa Menggunakan Newman's Error Analysis (NEA) pada Pemecahan Masalah Operasi Hitung Bentuk Aljabar. Prosiding Seminar Nasional \& Internasional. 